症例報告

$$
\begin{gathered}
\text { イトラコナゾール・パルス療法を実施した } \\
\text { 猫のクリプトコックス症の1例 }
\end{gathered}
$$

\title{
Cryptococcosis in a Somali Treated with Itraconazole Pulse Therapy
}

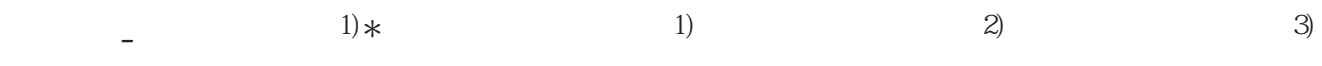 \\ 1)川口動物医療センター， ${ }^{2}$ 日本大学生物資源学部獣医学科， ${ }^{3)} A S C$ どうぶう皮膚病センター \\ Eri Kitamiya-Munakata ${ }^{1) *}$, Jun Ando ${ }^{1)}$, Rui $\mathrm{Kano}^{2)}$, Masahiko Nagata ${ }^{3)}$ \\ ${ }^{1)}$ Kawaguchi Animal Medical Center, ${ }^{2}$ Department of Veterinary Medicine, Nihon University, \\ ${ }^{3)}$ Animal Dermatology Center, ASC
}

\begin{abstract}
要 約:ソマリ，6歳齢，雌に，左耳孔のびらんを伴う結節および左耳下腺領域皮下の腫脹がみられ た。抗生斉で台療後, 病理組織学的検査を施行し円形ないし楕円形のPA S染色陽性酵母樣真菌要素 が多数認められた。真菌培養検査でCryptococcus neoformansが分離され，クリプトコックス症と診 断した。イトラコナゾール $7 \mathrm{mg} / \mathrm{kg} / \mathrm{sID}$ によ 2カ月後に皮疹は消退 , $5 \mathrm{mg} / \mathrm{kg} / \mathrm{sID}$ としさらに4カ月 治療を継続したが抗原検査陽性が持続し，パルス療法(同量1週間投与3週間休薬)に移行した。6力 月後に抗原試験は陰性となり休薬，弚の後皮疹の新生を認めていない。 キーワード：イトラコナゾール・パルス療法 , クリプトコックス症 , 猫
\end{abstract}

\begin{abstract}
A-6-year-old, female, Somali was presented with erosive nodule on the entrance to the left ear canal and subcutaneous swelling at the left parotid region. The cat was treated with antimicrobials, then skin biopsy was performed. Histopathological examination revealed numerous round or oval, PAS-positive, yeast-like organisms, and Cryptococcus neoformans was isolated with fungal culture. This cat was diagnosed as having cryptococcosis, and treated with once daily oral itraconazole (ICZ) $7 \mathrm{mg} / \mathrm{kg}$. Two months later, skin lesions were disappeared, but serum cryptococcal antigen was still positive after consecutive 4 months ICZ administration. Then ICZ pulse therapy was carried out for next 6 months, and finally conduced the antigen negative.
\end{abstract}

Key words: itraconazole pulse therapy, cryptococcosis, cat

(Jpn J Vet Dermatol 2007, 13 (4): 199-202)

緒 言

クリプトコックス症は, 主にCryptococcus neoformans に起因する感染症で散発的に発生している。C. neoformansは自然界に広く分布し, 鳩, カナリア, オ
ウムなど鳥類の粪便および炎の塵埃から高率に分離さ れる。本症はこれらを感染源とし, 経気道的もしくは 経皮的に感染する日和見感染症である。猫では鼻腔か ら発症し, 顔や脳に波及するとともに, 皮膚や肺に肉 芽腫病変が形成される。最近の報告によると, クリプ

\footnotetext{
*連絡先 (現勤務先) : 北宮 - 宗像絵里 (あさか台動物病院)％ 351-0025 埼玉県朝霞市三原 3-30-7

TEL 048-476-9991ＦAX 048-476-9939Ｅ-mail: erisko25@yahoo.co.jp

*Correspondence to: Eri Kitamiya-Munakata (Asakadai Animal Hospital) 3-30-7 Mihara, Asaka-shi, Saitama 351-0025, Japan
} 
トコックスは無症候猫の鼻腔内からも分離され，初期 感染巣として上部気道が指摘されている4)。今回猫の 耳道付近にクリプトコックス症が生じ， イトラコナ ゾール内服により皮疹消失後 , パルス療法による長期 管理によって抗原試験が陰性になった症例を経験した ので報告する。

\section{症例報告}

症例は幼少より屋内で飼育されていた6歳齢，雌の ソマリ (体重 $2.28 \mathrm{~kg}$ ) で, 左耳から出血がみられ平成 17年12月25日川口動物医療センター受診となった。左 外耳孔にびらん，血腫樣の隆起を伴う自傷がみられ (Fig. 1), 左耳下腺領域皮下に軽度の腫脹も観察され た。飼い主は約 3カ月前に左耳孔の発赤に気がついて おり，発症前後の薬物歴はなかった。耳を除き他の皮 膚に特記すべき異常なく，呼吸器症状を含めた他藏器 の症状はみられなかった。自傷阻止を目的としてカ ラーを装着し , エンロフロキサシン (バイトリル , バ イエルメディカル株式会社, 東京) $5 \mathrm{mg} / \mathrm{kg} / \mathrm{SID}$ の内服 およびゲンタマイシン外用薬 (ゲンタシン軟亳, シェ リング・プラウ株式会社, 大阪) の塗布にて1週間治 療を行なったが改善なく，耳孔付近の結節が増大し， 出血もみられ，左耳下腺領域の腫脹はより顕著になっ た (Fig. 2)。血液検査では, 好中球増多による白血球 増加症 $(33,990 / u l)$, 貧血 (PCV；24\%) がみられたが， 血液化学検査, 胸部X線検査, FIV 抗体, FeLV抗原検 査にて特記すべき異常はみられなかった。麻酔下にて 耳道内を観察したところ, 耳道から耳下腺領域皮下結 節につながる瘻管がみられた。耳道内結節および耳下 腺領域皮下結節を採取し，病理検査に供した。病理組 織像は，真皮全層にわたり，組織球と好中球を主体と した細胞浸潤と共に円形ないし棈円形PAS染色陽性の 酵母樣菌要素を多数認め, 兴の周囲は泡沫状の空胞構 造を呈していた(Fig. 3)。組織培養検査でCryptococcus neoformansが分離され , クリプトコックス症と診断し た。またラテックス凝集反応にて血清クリプトコック ス抗原検査 (Pastorex cryptoplus, Sanofi Diagnostics Pasteur, Marnes la coquette, France)を行ったところ，陽 性であった。

イトラコナゾール $7 \mathrm{mg} / \mathrm{kg} / \mathrm{SID}$ (イトリゾール , ヤン センファーマ株式会社 , 東京) , ファロペネム $7 \mathrm{mg} / \mathrm{kg} /$

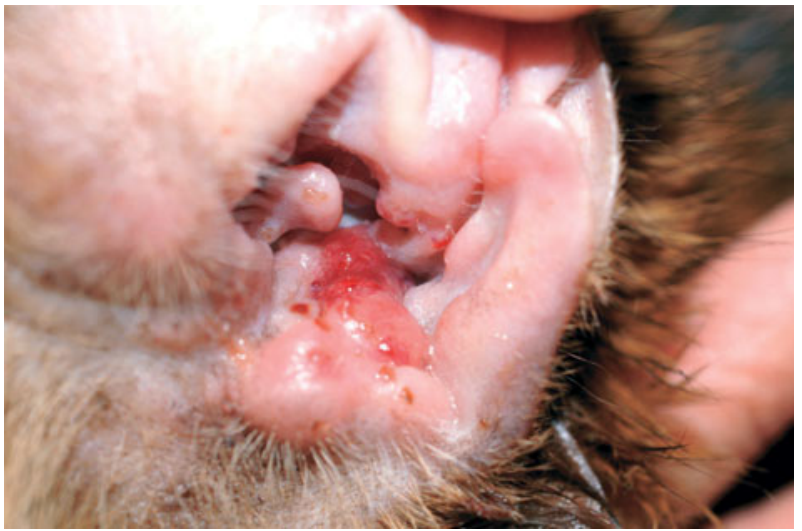

Fig. 1. Clinical features of the cat. Note nodules with erosion at the entrance to the external ear canal.

(A)

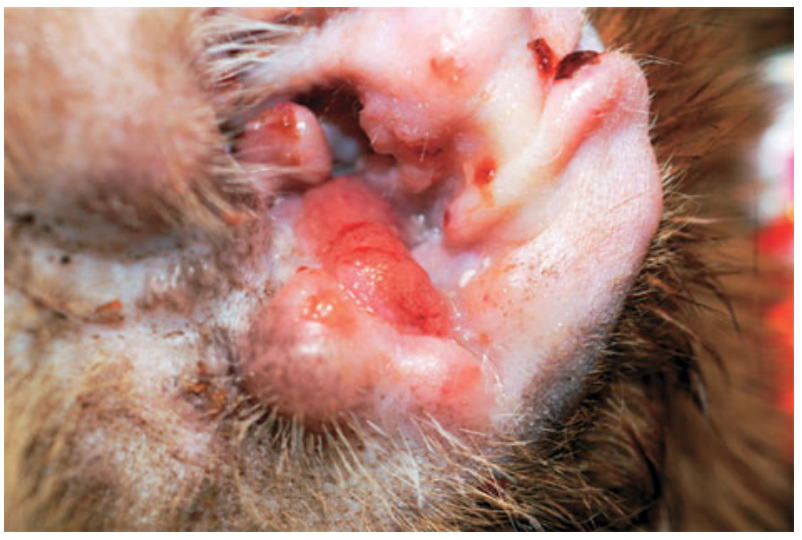

(B)

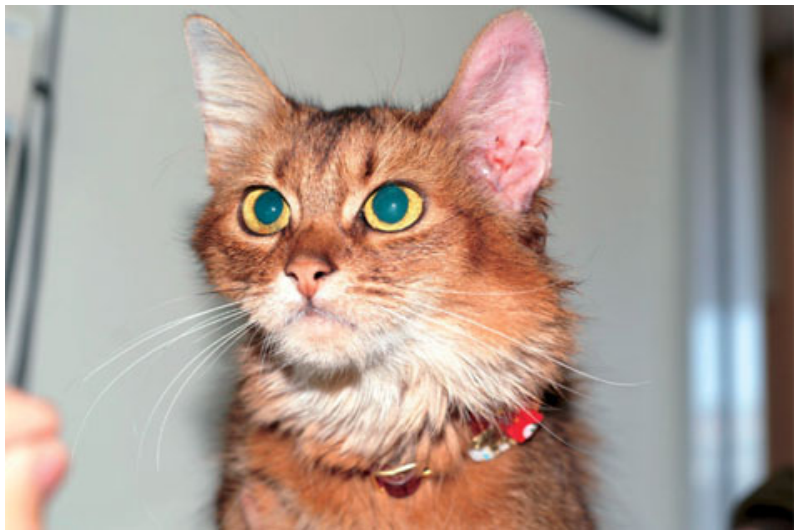

Fig. 2. Clinical features before itraconazole administration. (A) Note enlarged masses with hemorrhage. (B) Note swelling around the left parotid region.

BID (ファロム，マルホ株式会社，大阪）の内服を開 始した。2週間後に耳孔のびらんは乾燥し，耳下腺領 域の腫脹も縮小傾向を示した。5週間後にはびらんが 
(A)

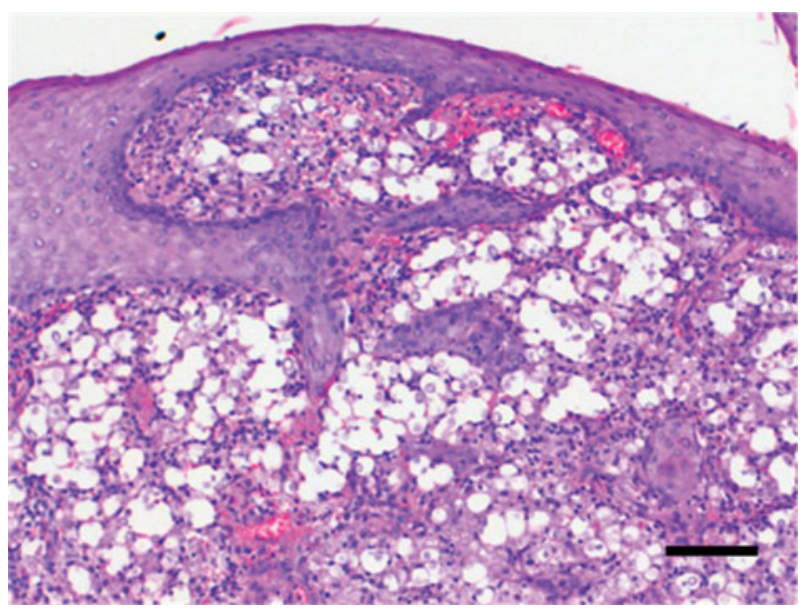

(B)

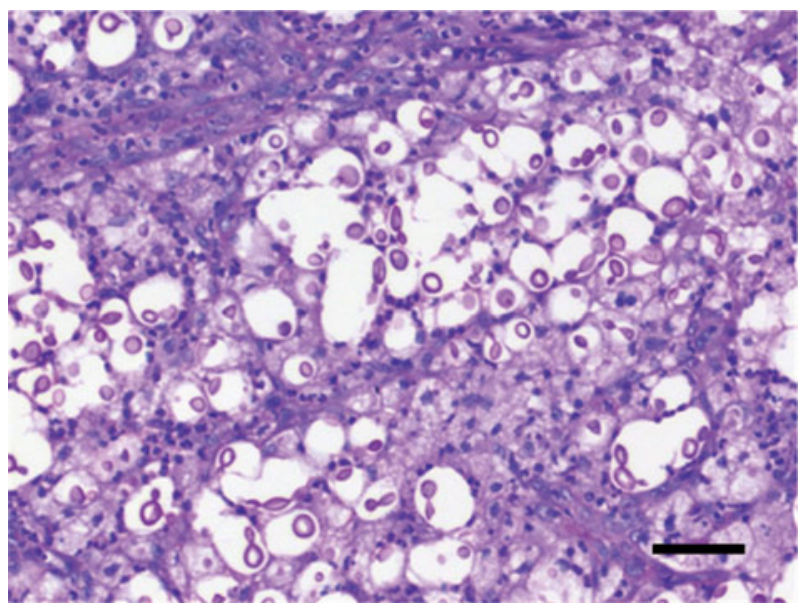

Fig. 3. Histopathological findings of the lesion. (A) Note diffuse foamy appearance due to accumulation of the organisms with scant inflammation in the dermis. H\&E stain. Bar=100 $\mu \mathrm{m}$. (B) Note prominent capsulation of the organisms. PAS stain. Bar $=50 \mu \mathrm{m}$.

ほぼ消退し，耳下腺領域の腫脹はかなり縮小したが， 血清クリプトコックス抗原は陽性であった。治療開始 2力月後に皮疹はほほ軽快した。血液検査で依然貧血 (PCV ; 26\%) がみられたが, 白血球増多は改善し，イ トラコナゾール内服による副作用もみられなかった。 クリプトコックス症では, 軽快後休薬による皮疹の新 生が報告されていることから ${ }^{2,7)}$ ，イトラコナゾールの 投与用量を $5 \mathrm{mg} / \mathrm{kg} / \mathrm{SID}$ に減量し継続投与した。治療 開始4カ月後皮疹はまったくみられず, 血液検査で貧 血の改善傾向 (PCV; 30\%) も認められたが，血清ク リプトコックス抗原の陽性が持続した。イトラコナ ゾール5 $\mathrm{mg} / \mathrm{kg} / \mathrm{SID}$ をさらに2月継続し，都合半年間
の治療を行ったがクリプトコックス抗原の陽性か持続 した。クリプトコックス症におけるイトラコナゾール 治療は，抗原が陰性になるまで継続すべきであるが3， 症状が消退してからすでに4カ月が経過しており，光 の副作用および治療費を懸念してイトラコナゾール 7 $\mathrm{mg} / \mathrm{kg} / \mathrm{SID}$ によるパルス療法 (1週間投薬後3週間休薬) に移行した。イトラコナゾール・パルス療法を開始し てから，6力月後 (発症1年後) にようやく血清クリプ トコックス抗原は陰性となり治療を終了，すでに9カ 月経っているが，これまでのところ皮疹の新生は認め られない。

\section{考 察}

本症例はペットショップて購入されてからベランダ に出ることもない完全な室内飼育で，飼育当時よりく しゃみなどの呼吸器症状はみられず, 病変の分布は耳 道および耳下腺領域皮下に限局していた。また，宿主 免疫異常として感染猫では約 $50 \%$ に FeLV 感染ありと 指摘されているが6)，自験例はFeLV，FIV 共に陰性で あり，ステロイドを含めた先行する薬物歴や免疫抑制 を示唆する症状および検査成績もまったくみられな かった。感染経路や発症機序に関しては不明であった が，少なくとも持続的な感染源を有した重篤な日和見 感染とは思われなかった。

クリプトコックス症の治療として , これまでイトラ コナゾール , ケトコナゾール , フルコナゾール , アン ホテリシンBなどが用いられているが，最近はイトラ コナゾールやフルコナゾールが汎用されており，これ ら抗真菌薬が長期投与されている7)。猫のクリプト コックス症では抗真菌薬の平均投与期間が 8.5 月と 報告されているも5 ，休薬による再発がみられること から ${ }^{2,7}$, 症状消退後少なくとも1力月の継続投与か推 奨されている7。ラテックス凝集反応によるクリプト コックス抗原の測定は，治療転帰や予後を予測する指 標になりうることから ${ }^{9}$ ，理想的には血清クリプト コックス抗原か陰性になるまで台療を続けることか望 ましい3)。

実地診療において, 皮疹消退後も治療を継続する場 合, 飼い主の理解と協力が不可欠である。乥こで自験 例では，長期治療に配慮して寛解維持と抗原検査陰性 を目的としたイトラコナゾール・パルス療法を提案し 
た。医学領域においてイトラコナゾール・パルス療法 は，爪白癬で用されている。爪白癖に対するパルス 療法は，イトラコナゾールの良好な角質移行および長 期残留を根拠に行われており，兴のプロトコールは， $400 \mathrm{mg} /$ 日，1週間投薬，3週間休薬を1サイクルとし，

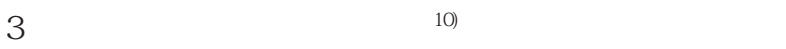
セチア皮膚炎に対し，イトラコナゾール・パルス療法 (5 mg/kg，2回/週) が検討されており，連日投与と比 較して兴の治療効果に差がないと報告されている8 ${ }^{8}$ 。 爪白癬に対する治療コンセプトとは異なるが，今回 は，潜在するクリプトコッカスに対し断続的にイトラ コナゾールを投与することで消極的ながら免疫系を援 助すべくパルス療法を実施した。われわれか調べ得た 限り，猫のクリプトコックス症に対するイトラコナ ゾール・パルス療法の報告はなく，あくまで試験的な 一治療としてパルス療法を導入した。幸いにして期待 通りの結果が得られたが, 弚の有用性に関しては今後 さらに症例を蓄積すると共に，治療プロトコールやパ ルス療法に切り替えるタイミングなどについて , 多角 的に検討を重ねる必要があると思われた。
参考文献

1) Jacobs, G.J., Medleau, L., Calvert, C. and Brown, J. 1997. J. Vet. Intern. Med. 11: 1-4.

2) Kano, R., Nakamura, Y., Watari, T., Tsujimoto, H. and Hasegawa, A. 1997. Mycoses 40: 381-383.

3) Malik, R., McPetrie, R., Wigney, D.I., Craig, A.J. and Love, D.N. 1996. Aust. Vet. J. 74: 358-364.

4) Malik, R., Wigney, D.I., Muir, D.B. and Love, D.N. 1997. J. Med. Mycol. 35: 27-31.

5) Medleau, L., Jacobs, G.J. and Marks, M.A. 1995. J. Vet. Intern. Med. 9: 39-42.

6) Mikiciuk, M.G., Fales, W.H. and Schmidt, D.A. 1990. J. Am. Anim. Hos. Assoc. 26: 199-201.

7) O’Brien, C.R., Krockenberger, M.B., Martin, P., Wigney, D.I. and Malik, R. 2006. Aust. Vet. J. 84: 384-392.

8) Pinchbeck, L.R., Hillier, A., Kowaiski, J.J. and Kwochka, K.W. 2002. J. Am. Vet. Med. Assoc. 220: 1807-1812.

9) Scott, D.W., Miller, W.H. and Griffin, C.E. 2001. pp. 395400. In: Small Animal Dermatology, 6th ed, W.B. Saunders, Philadelphia.

10) Watanabe, S. 2004. Jpn. J. Med. Mycol. 45: 143-147. 